\title{
Some aspects of peripartum, neonate and foal heat in mini pony mares
}

\author{
Adriana Pires Neves', Ivan Cunha Bustamente-Filho², Caroline Antoniazzi Wolf², Fabiana Santos Castro², Gabriela Richter², \\ Felipe François Motta'2, Gabriel Monteiro Davolli2, Giovani Casanova Camozzato², Gustavo Ferlini Agne², \\ Ricardo Macedo Gregory ${ }^{2}$ and Rodrigo Costa Mattos ${ }^{2}$
}

UNIPAMPA- Universidade Federal do Pampa; Dom Pedrito, RS, Brazil' and REPROLAB - Faculdade de Veterinária, UFRGS, Porto Alegre, RS, Brazil²

\begin{abstract}
Summary
Physiological aspects of the peripartum period are well known in the Thoroughbred breed. The aim of this study was to establish some physiological parameters of the miniature mare and foal during the same period. Nine Brazilian Pony breed mares mean age 7.5 years old were used. Parameters investigated were: length of gestation; time for placenta deliverance; time for umbilical cord rupture; time for the neonate to stand; time to present suckling reflex; time that the foal took to nurse; time for meconium elimination. Foals height and weight were also measured. Mares were examined by transrectal palpation and ultrasonography from the day following parturition to the 6 th day after the second postpartum ovulation, to record follicular development and the onset and duration of foal heat. 7 mares had live foals, and 2 had dystocia (28.5\%). Gestational length was 328.3 \pm 12.5 days. All births occurred between 01:17 and 04:50 a.m. Umbilical cord took $3.2 \pm 2.3$ min to rupture, and placentae were delivered mostly at $34.2 \pm 6.3$ min after parturition, weighing an average of $1.36 \pm 0.1 \mathrm{~kg}$. The foals stood up in $19.2 \pm 9.9 \mathrm{~min}$ and showed suckling reflex in $13.8 \pm 9.8 \mathrm{~min}$. First nursing occurred at $69.6 \pm$ $36.9 \mathrm{~min}$; and meconium elimination at $73 \pm 50.5 \mathrm{~min}$ after birth. Foals' mean height was $58.5 \pm 5.07 \mathrm{~cm}$ and weight was $14.8 \pm 12.1$ $\mathrm{kg}$. The first postpartum ovulation occurred $18.6 \pm 9.9$ days after parturition. Most of the observed parameters show a difference from data existing on normal size mares. However, more studies are needed to assess all the parameters concerning the foal and the miniature mare's puerperium.
\end{abstract}

Keywords: Reproduction, minipony mares; parturition; foal; foal heat

\section{Einige Aspekte über die Peripartalphase, die Neonaten und die Fohlenrosse bei Minipferdstuten}

Physiologische Aspekte über die peripartale Phase bei Vollblutstuten sind ausführlich dokumentiert. Das Ziel dieser Studie war es, vergleichbare physiologische Abläufe bei Stuten und Fohlen der Rasse "Pônei Brasileiro" in diesem Zeitraum zu untersuchen. Es wurden 9 Ponystuten mit einem Altersdurchschnitt von 7,5 Jahren eingesetzt. Das Abfohlen erfolgte bei freier Weidehaltung, der genaue Zeitpunkt der letzen Ovulation war bei allen Stuten bekannt. Folgende Parameter wurden erhoben: Daver der Trächtigkeit; Zeit bis zum Abgang der Plazenta; Zeit bis zum Abriss der Nabelschnur; Zeit bis zum Aufstehen des Fohlens; Zeit bis zum Einsetzen des Saugreflexes, Zeit bis zum ersten Saugen des Fohlens, Zeit bis zum Abgang des Mekoniums. Größe und Gewicht der Fohlen wurden einen Tag nach der Geburt bestimmt. Die Stuten wurden vom 1. bis 6. Tag nach dem Abfohlen rektal palpatorisch und ultrasonographisch untersucht, ebenfalls während der zweiten Ovulation post partum, um die Entwicklung der Follikel und das Einsetzen sowie die Daver der Fohlenrosse festzustellen. Von den 9 erwarteten Geburten wurden von 7 Stuten lebende Fohlen geboren, zwei tote Fohlen wurden nach Dystokie (28,5\%) entwickelt. Die Trächtigkeitsdaver betrug 328,3 \pm 12,5 Tage. Die Geburten fanden alle nachts zwischen 01:17 und 04:50 Uhr statt. Der Zeitpunkt des Abreißens des Nabels erfolgte nach 3,2 \pm 2,28 Minuten, die Nachgeburt wurde 34,2 \pm 6,26 Minuten nach der Geburt mit einem Gewicht von 1,36 $\pm 0,14$ kg abgestoßen. Der Zeitraum bis die Fohlen aufstanden betrug 19,2 \pm 9,86 Minuten, und der Saugreflex setzte nach 13,8 \pm 9,78 Minuten ein. Das erste Saugen erfolgt nach 69,6 \pm 36,88 Minuten, der Abgang des Mekoniums nach 73 \pm 50,53 Minuten post natum. Die durchschnittliche Höhe der Fohlen betrug $58.5 \pm 5.07 \mathrm{~cm}$ und ihr Gewicht lag bei $14.76 \pm 12.13 \mathrm{~kg}$. Bei den Minipferdstuten setzte die Fohlenrosse später als der erwartete Zeitpunkt ein. Die erste Ovulation post partum stellte sich 18,57 $\pm 9,86$ Tage nach der Geburt ein. Zwei Stuten zeigten einen Anöstrus post partum, eine nach Dystokie, die andere nach der ersten Ovulation post partum. Die meisten Untersuchungsergebnisse weisen Unterschiede zu den Parametern von Stuten mit normaler Größe auf. Es bedarf weiteren Untersuchungen, um alle Parameter zu den Fohlen und dem Puerperium bei Miniponies festzulegen.

Schlüsselwörter: Reproduktion, Minipony Stuten; Geburt; Fohlen; Fohlenrosse

\section{Introduction}

Interest in Miniature ponies/horses has grown during the last 10 years. The Miniature horse industry has registered more than 100,000 horses throughout the world. It has been stated that miniature horses can not be seen as a smaller version of larger breeds, due to years of breeding selection and unique physiological and metabolical demands (Frankeny 2003). Studies in miniature mares have fundamental and practical importance for formulating and testing hypothesis of physiological events, allowing precise diagnosis and treat- ments in reproductive practice. Although there are a few clinical reports in miniature mares (Judd 1994, Tibary 2004), detailed scientific studies were only performed recently on follicular, luteal, and endometrial dynamics (Gastal et al. 2008) and also endocrinology (Ginther et al. 2008) during the estrous cycle. The physiological aspects of the peripartum and neonatal period are well studied in the Thoroughbred breed (Koterba et al. 1990, Kurtz Filho 1995). However, in the Miniature Pony breeds, in which usually parturition occurs unattended, in the field, most of these parameters are unknown. The aim of this study was to establish some physio- 
logical parameters of minipony mares and foals during the peripartum period, allowing then to differentiate from abnormal or pathological situations.

\section{Material and methods}

Nine mares of the Brazilian Pony breed were used. The average age of mini-pony mares was 7.5 years old. Mares had their parturition assisted on the field. Mares were kept in small paddocks located at the Faculdade de Veterinária of the Universidade Federal do Rio Grande do Sul (30 $01^{\prime} 58^{\prime \prime} \mathrm{S} 51^{\circ}$ $\left.13^{\prime} 48^{\prime \prime} \mathrm{O}\right)$. Mean body condition score of these mares was 3 (in a scale of 1-5). Animals were divided in groups of 3 mares when they showed signs of impending parturition. Since the day of last ovulation was known, length of gestation was one of the parameters investigated, together with: time for deliverance of placenta; time for umbilical cord rupture; time for the neonate to stand; time to present suckling reflex; time that the foal took to nurse. Time necessary for meconium elimination was also observed. Foals height and weight were measured in the day following birth. Mares were also palpated and ultrasound scanned daily from the day following parturition to the 6th day after the second postpartum ovulation, to record follicular development and the onset and duration of foal heat. An ultrasound B-mode instrument (Aloka SSD500V; Aloka, Wallingford, CT, USA) equipped with a $5 \mathrm{MHz}$ linear-array transrectal transducer (Gastal et al. 1998) was used for evaluation of the ovaries and uterus.

\section{Results and Discussion}

From the 9 parturitions expected, 7 mares had live foals, and 2 dystocic parturitions (28.5\%) with dead foals. Results are shown in table 1 and 2 .

All births occurred during the night, between 01:17 and 04:50 a.m. The miniponies gestation length was from $328.3 \pm 12.5$ days, shorter than the 341 days observed by Koterba et al. (1990) in mares. Obviously, miniature foal's
$(14.8 \mathrm{~kg})$ and placenta's $(1.4 \mathrm{~kg})$ weight were lighter than the observed by Löf (2009) in Thoroughbred mares (placenta $6.4 \mathrm{Kg}$; foal $-55.5 \mathrm{~kg}$ ). Time taken by the minipony foal to stand up (19.2 \pm 9.9) and to nurse the mare (69.6 \pm 36.9) were shorter when compared with the observations of Koterba et al. (1990) and from Kurtz Filho (1995) where foals stand up 57 and 49 minutes and took the first nurse with 111 and 94 minutes after delivery respectively. Probably the light weight and height of the minipony foals make possible more agility and motor coordination to stand up and to nurse more quickly than bigger foals.

Two mares showed postpartum anoestrus, one after dystocia and the other after the first postpartum ovulation. The minipony mares showed a delay in the expected date for foal heat. The first postpartum ovulation occurred $18.6 \pm 9.9$ days after parturition. This agrees with the study of Neves et al. (2000), in minipony mares, in which the first postpartum ovulation occurs $26.6 \pm 6.5$ days after parturition. The data are similar to the findings of Nagy et al. (1998), who found, in normal size mares, an interval of $17.8 \pm 16.6$ days from foaling to first ovulation. However, such a delay is not commonly seen in normal size mares (Mattos et al. 1995, Malschitzky et al. 2001). Most of the observed parameters in this study show a difference from pre-existing data in normal size mares. However, more studies are needed to assess all the parameters concerning the foal and the miniature mare's puerperium. Delay on first postpartum ovulation could be due to the breed's intrinsic adaptive factors.

\section{References}

Frankeny R. L. (2003) Miniature horses, a veterinary guide for owners and breeders. North Pomfret, VT: Trafalgar Square Publishing.

Gastal E. L., A. P. Neves, R. C. Mattos, B. P. L. Petrucci, M. O. Gastal and $O$.J. Ginther (2008) Miniature ponies: 1. Follicular, luteal, and endometrial dynamics duringthe oestrous cycle. Reprod. Fertil. Develop. 20, 376-385

Gastal E. L., M. O. Gastal and O. J. Ginther (1998) The suitability of echotexture characteristics of the follicular wall for identifying the optimal breeding day in mares. Theriogenology 50, 1025-1038

Table 1 Parturition data related to the mare / Daten zur Geburt der Ponystuten

\begin{tabular}{lll}
\hline Parameters of the mare & Value (Mean \pm SD) & Range \\
\hline Gestational length & $328.3 \pm 12.5$ & $314-344$ \\
Umbilical cord rupture (min) & $3.2 \pm 2.3$ & $1-6$ \\
Placental delivery (min) & $34.2 \pm 6.3$ & $25-41$ \\
Placenta weight (kg) & $1.36 \pm 0.1$ & $1.2-1.5$ \\
Postpartum ovulation (days) & $18.57 \pm 9.9$ & \\
\hline
\end{tabular}

Table 2 Parameters related to foals / Parameter der neugeborenen Fohlen

\begin{tabular}{lll}
\hline Parameters of the foals & Value (Mean \pm SD) & Range \\
\hline Foal weight $(\mathrm{kg})$ & $14.8 \pm 12.1$ & $12-18.5$ \\
Foal height $(\mathrm{cm})$ & $58.5 \pm 5.1$ & $51-62$ \\
Suckling reflex (min) & $13.8 \pm 9.8$ & $4-30$ \\
Stand up (min) & $19.2 \pm 9.9$ & $10-36$ \\
First nursing (min) & $69.6 \pm 36.9$ & $20-119$ \\
Meconium elimination (min) & $73 \pm 50.5$ & $16-122$ \\
\hline
\end{tabular}


Ginther O. J., M. A. Beg, A. P. Neves, R. C. Mattos, B. P. L. Petrucci and M. O. Gastal (2008) Miniature ponies: 2. Endocrinology of the oestrous cycle. Reprod. Fertil. Develop. 20, 386-390

Judd R. C. (1994) A practitioner's approach to reproductive problems in miniature mares. Equine Pract. 16, 9-14

Koterba A. M., W. H. Drummond and P. C. Kosch (1990) Equine Clinical Neonatology. Lea \& Febiger, Philadelphia, 55-70

Kurtz Filho M. (1995) Aspectos Fisiológicos do pós-parto na égua e no potro recém-nascido. Ciência Rural 25, 502-505

Löf H. K. (2009) Características da conformação vulvar, espessura da junção útero-placentária e exames histopatológicos de placenta em éguas Puro Sangue de Corrida no Rio Grande do Sul.Dissertação (Master Science), Universidade Federal do Rio Grande do Sul, 41 pp.

Malschitzky E., A. Schilela, L. S. Meirelles, A. L. G. Mattos, R. M. Gregory and R. C. Mattos (2001) Artificial photoperiod in pregnant mares andits effect on pregnancy length and postpartum reproductive performance. Pferdeheilkunde 17, 565-569

Mattos R. C., A. L. A. Rocha, O. Zimmer Jr., R. Mattos, V. B. Wald and R. M. Gregory (1995) Use of Methylergonovine Maleate and Cloprostenol during Uterine Involution to Improve Conception Rates of Foal Heat. Biol. Reprod. Mono. 1, 533-537
Nagy P., G. Huzsenicza, J. Juhász, M. Kulcsár, L. Solti, J. Reicziegel and K. Abaváry (1998) Factors influencing ovarian activity and sexual behavior of postpartum mares under farm conditions. Theriogenology 50, $1109-1119$

Neves A. P., A.O. Becker, G. Möller, E. L. R. Brito, C. R. Trein, R. M. Gregory and R. C. Mattos (2000) Parámetros reproductivos en yeguas de la raza brasileña de poneys In: I Congreso de Medicina Equina - Asociación Argentina de Veterinarios de Equinos, 2000, Buenos Aires. I Congreso de Medicina Equina - Asociación Argentina de Veterinarios de Equinos

Tibary A. (2004) Reproductive patterns in donkeys and miniature horses. Proceedings North American Veterinary Conference. Large Animal 18, 231-233

Adriana Pires Neves

adripneves@yahoo.com.br

Universidade Federal do Pampa

Rua Borges de Medeiros, 1769

96450-000- Dom Pedrito, RS

Brazil 